\title{
Association of Multi-Drug Resistance-1 (MDR1) Gene Polymorphism with Leukocytopenia in Breast Cancer Patients treated with Chemotherapy
}

\author{
Siti Syarifah ${ }^{1}$, Tri Widyawati ${ }^{2}$, Kamal B.Siregar ${ }^{3}$, Yahwardiah Siregar $^{4}$ \\ 1,2 Department of Pharmacology and Therapeutic, Universitas Sumatera Utara, Indonesia \\ syarifah8512@yahoo.com \\ tw_rozan@yahoo.com \\ ${ }^{3}$ Department of Surgery Subdivision Oncology Surgery, Universitas Sumatera Utara, Indonesia \\ kamalbasrisiregar@yahoo.com \\ ${ }^{4}$ Department of Biochemistry, Biomedical Master Programme, Universitas Sumatera Utara, Indonesia \\ yahwardiah@yahoo.com
}

\begin{abstract}
Breast cancer incidence rates tend to increase in Indonesia and worldwide. Chemotherapy is an important breast cancer treatment which improve survival rate but also has many side effects. Leukocytopenia is one of the most common side effects that can be life-threatening due to opportunistic infection. Genetic polymorphism has been linked to inter-individual variations in terms of toxicity response of anticancer drugs. C3435T polymorphism in exon 26 of Multi-Drug Resistance 1 (MDR-1) gene which encodes P-glycoprotein (P-gp) is considered to be associated with increase of leukocytopenia incidence during chemotherapy. This study aim to investigate the association between MDR1 C3435T polymorphism with the grading of leukocytopenia in breast cancer patients treated with chemotherapy. 72 Indonesian female breast cancer patients from Haji Adam Malik Hospital who received chemotherapy containing doxorubicin-paclitaxel were selected for this cohort study. DNA was extracted from peripheral leukocytes and MDR1 C3435T polymorphism was analyzed with polymerase chain reaction restriction fragment length polymorphism (PCRRFLP). Patient data were collected for 3 cycles of chemotherapy. Association between MDR1 C3435T polymorphism with the grading of leukocytopenia was assessed using Kruskal-Wallis test. Decline of absolute leucocyte count during 3 cycles of chemotherapy was assessed using Wilcoxon test. Genotype deviation and allele frequencies were also determined by HardyWeinberg Equilibrium. Patients were divided into 4 ethnics: Bataknese, Minangkabau, Javanese and Acehnese. Distribution of MDR1 C3435T polymorphism was varied among these ethnics. The frequencies of MDR1 C3435T genotype for wildtype (CC) was $22(30,6 \%)$, heterozygous (CT) was $38(52,8 \%)$ and homozygous mutant (TT) was $12(16,7 \%)$. There was no association between MDR1 C3435T polymorphism and the grading of leukocytopenia $(p>0,05)$. The average of absolute leukocyte count was differ after the second chemotherapy and after the third chemotherapy $(p<0,05)$. The allele and genotype frequency from Hardy-Weinberg Equilibrium showed no significant deviation. MDR1 C3435T polymorphism had no association with leukocytopenia in breast cancer patients treated with doxorubicin-taxan regimen, meanwhile there was a trend of absolute leukocyte count declining post chemotherapy cycle 2 .
\end{abstract}

Keywords - MDR1 C3435T polymorphism, leukocytopenia, doxorubicin-paclitaxel, breast cancer

\section{I.INTRODUCTION}

Breast cancer is the second most common cancer overall in women worldwide with nearly 1,7 million new cases in 2012 [1]. In Indonesia, breast cancer is the most common cancer among women with incidence rates are 26 per 100.000 women and breast cancer patients have the highest number of hospitalization with percentage is $16,86 \%$. The total number of hospitalized breast cancer patients in Adam Malik Hospital, Medan, Indonesia, were 532 women in 2012 and majority of cases were diagnosed in late stages [2].

Chemotherapy is the important breast cancer treatment which improve survival rates but also has many side effects. One of the most common adverse event is leukocytopenia which can be life threatening definitely by opportunistic infection [3]. These resulting in reduction of anticancer drug's doses and delays chemotheraphy which compromise treatment outcomes [4], [5]. Human Multidrug Resistance Gene (MDR1) encodes Pglycoprotein (P-gp), a 170-kDa multidrug transporter/ efflux pump. P-gp responsible for efflux of wide variety of liphophilic compounds, including multiple chemotherapeutics agents such as antracycline (doxorubicin), taxanes (docetaxel, paclitaxel), alcaloid vinca, epidopolitoxin and tamoxifen. P-gp is expressed primarily in gastrointestinal tract, liver, kidney, testis, placenta, 
blood-tissue barrier,breast, bone marrow and peripheral leukocytes [6],[7],[8].

Nowadays, more than 100 variants of MDR1 gene have been reported. One of these, a silent single nucleotide polymorphism which located in nucleotide position 3435 that change cytosine base (C) to Thymin base (T) on exon 26 (C3435T) has been found to be associated with altered P-gp function [9],[10]. Several studies showed SNP C345T, TT homozygotes had significantly decreased duodenal P-gp expression, in CD56+ natural killer cells and in cell lines derived from ovary, mammary and kidney [11], [12]. In hematological toxicities, homozygous variant (TT) have 1,5 times of absolute neutrophil count declining than group which have wildtype genotype (CC) [13].

Based on differential expression, those patients with low-expressing MDR1 genetics variant (TT homozygous) could be more likely to doxorubicinpaclitaxel induced leukocytopenia. Therefore, we investigated the association of MDR1 gene C3435T polymorphism with the grading of leukocytopenia in breast cancer patients.

\section{II.METHOD}

72 Indonesian breast cancer patients from Haji Adam Malik Hospital who had been diagnosed and treated with doxorubicin-paclitaxel regimen were selected for this cohort study from February to August 2014. Eligible patients had histological confirmed breast cancer, had planned to get paclitaxel-doxorubicin regimen, range of age 16-68 years old, had a normal of liver function and kidney function, had a normal complete blood count (CBC), available to sign informed consent. Patient who smoking, had a history of cardiac disease, hematologic disease and had previous radiotherapy 3 month before were excluded from this study.This study was approved by medical faculty Ethic Committe.

Blood samples were taken from anticoagulated (EDTA) peripheral venous blood. Genomic DNA were extracted using genomic DNA Purification Kit (Promega Corporation, USA). SNP in MDR1 (C3435T in exon 26) was analyzed by PCR-RFLP assay using the primer sequences 5'TGTTTTCAGCTGCTTGATGG-3' and 5'-
AAGGCATGTATGTTGGCCTC-3'. $5 \mu$ of PCR product was digested by 1 unit restriction endonuclease enzyme Sau3AI (Promega) at 370C for 2 hours. Digested products were separated by $2 \%$ agarose gel electrophoresis and observed directly under UV light after staining with Ethidium Bromide. Electrophoresis patterns showed one band (158 bp) for homozygous wildtype (CC), two bands (197 and $158 \mathrm{bp}$ ) for heterozygous variant (CT) and one band (197 bp) for homozygous variant (TT). Leukocytopenia data and characteristic of subjects was collected from medical records for 3 cycles of chemotherapy. Leukocytopenia will be classified into grade 1-4 based on Common Terminology and Criteria of Adverse events (CTCAE).

SPSS software for Windows (SPSS version 19.0) was used for statistical analyses. The association of polymorphism with grading of leukocytopenia will be analyse by using Kruskal Wallis test. To analyse trend of absolute neutrophil count declining, we use wilcoxon test. $p<0,05$ was considered statistically significant. Distribution of allele frquency and genotype will calculate by using Hardy-Weinberg Equilibrium.

\section{RESULT}

Patients characteristic are shown in Table 1. The CC genotype was found in $22(30,6 \%)$ patients, CT genotype in $38(52,8 \%)$ patients and TT genotype was found in $12(16,7 \%)$ patients. We found 4 ethnics that were Bataknese, Minangkabau, Javanese and Acehnese. Distribution of MDR1 C3435T was varied among these ethnics. Bataknese had the highest frequency of homozygous CC genotype (wildtype) with $12(54,50 \%)$, Javanese had the highest frequency of heterozygous varian (CT) with $21(55,30 \%)$ and we found homozygous variant (TT) as the lowest among all ethnics. There was no association between MDR1 C3435T polymorphism with the grading of leukocytopenia ( $>>0,05)$ for post chemotherapy cycle 1 , cycle 2 and cycle 3 . The results were summarized in table 2 , table 3 and table 4, respectively. 
TABLE I

PATIENTS CHARACTERISTIC

\begin{tabular}{|l|l|}
\hline Variables & $\mathbf{N}(\boldsymbol{\%})$ \\
\hline Group of age & \\
\hline$<35$ & $2(2,8 \%)$ \\
\hline $36-55$ & $51(19,4 \%)$ \\
\hline $56-65$ & $17(40,3 \%)$ \\
\hline$>65$ & $2(27,8 \%)$ \\
\hline Education History & \\
\hline Elementary school & $11(15,3 \%)$ \\
\hline Junior High school & $15(20,8 \%)$ \\
\hline Senior High school & $36(50 \%)$ \\
\hline Academician degree & $10(13,8 \%)$ \\
\hline Ethnic & \\
\hline Javanese & $30(41,7 \%)$ \\
\hline Bataknese & $29(40,3 \%)$ \\
\hline Acehnese & $10(13,9 \%)$ \\
\hline Minangkabau & $3(4,2 \%)$ \\
\hline Family History & \\
\hline Negative & $70(97,2 \%)$ \\
\hline Positive & $2(2,8 \%)$ \\
\hline Contraceptive oral history & \\
\hline Negative & $54(75 \%)$ \\
\hline Positive & $18(25 \%)$ \\
\hline Stadium & \\
\hline II & $14(19,4 \%)$ \\
\hline III & $40(55,6 \%)$ \\
\hline IV & $18(25 \%)$ \\
\hline & \\
\hline
\end{tabular}

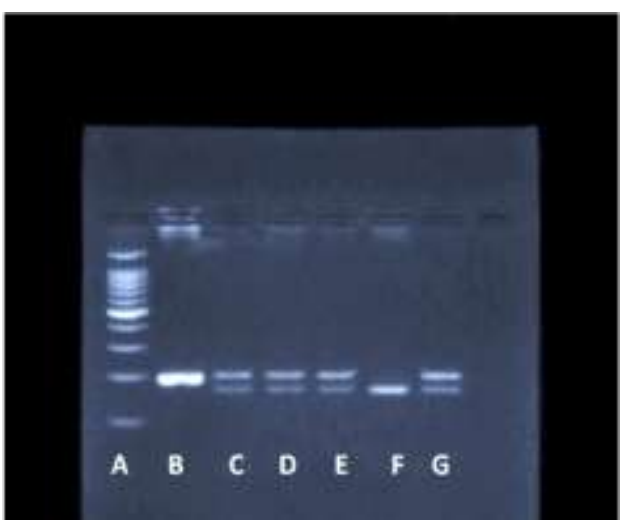

Fig 1. Electrophoretic pattern of MDR1 C3435T evaluated by PCR-RFLP assay: CC genotype ( F column), TT genotype ( B column), CT genotype ( C,D,E,G column), A ( 100 bp DNA ladder marker)

TABLE II

ASSOCIATION OF MDR1 C3435T WITH LEUKOCYTOPENIA POST CHEMOTHERAPY CYCLE 1

\begin{tabular}{|c|c|c|c|c|c|c|c|c|c|}
\hline \multirow[t]{3}{*}{ Polymorphism } & \multicolumn{6}{|c|}{ Post chemotherapy cycle I } & \multirow{2}{*}{\multicolumn{2}{|c|}{ Total }} & \multirow[t]{3}{*}{$\mathrm{P}$} \\
\hline & \multicolumn{2}{|c|}{ Normal } & \multicolumn{2}{|c|}{ Degree I } & \multicolumn{2}{|c|}{ Degree III } & & & \\
\hline & $\mathrm{n}$ & $\%$ & $\mathrm{n}$ & $\%$ & $\mathrm{n}$ & $\%$ & $\mathrm{n}$ & $\%$ & \\
\hline $\mathrm{CC}$ & 20 & 90,9 & 2 & 9,1 & 0 & 0 & 22 & 100 & 0,390 \\
\hline $\mathrm{CT}$ & 34 & 89,4 & 2 & 5,3 & 2 & 5,3 & 38 & 100 & \\
\hline TT & 11 & 91,7 & 1 & 8,3 & 0 & 0 & 12 & 100 & \\
\hline Total & 65 & 90,3 & 5 & 6,9 & 2 & 2,8 & 72 & 100,0 & \\
\hline
\end{tabular}

Kruskal-Wallis Test
In this study, no association between polymorphism of MDR1 gene C3435T and the grading of leukocytopenia was observed $(p>0,05)$. In this study, we can find trend of absolute leukocyte count declining (table 5). Distribution of frequency of alelle and genotype was using HardyWeinberg Equilibrium (Table 6). Based on table 6, $p>0,05$ which showed that there was no any significant deviation of alelle and genotype frequency from Hardy-Weinberg Equilibrium.

TABLE III

ASSOCIATION OF MDR1 C3435T WITH LEUKOCYTOPENIA GRADING POST CHEMOTHERAPY CYCLE II

\begin{tabular}{|c|c|c|c|c|c|c|c|c|c|}
\hline \multirow[t]{3}{*}{ Polymorphism } & \multicolumn{6}{|c|}{ Post chemotherapy cycle II } & & & $\mathbf{P}$ \\
\hline & \multicolumn{2}{|c|}{ Normal } & \multicolumn{2}{|c|}{ degree I } & \multicolumn{2}{|c|}{$\begin{array}{c}\text { degree } \\
\text { II }\end{array}$} & \multicolumn{2}{|c|}{$\begin{array}{l}\text { Degree } \\
\text { III }\end{array}$} & \\
\hline & $\mathrm{n}$ & $\%$ & $\mathbf{N}$ & $\%$ & $\mathbf{n}$ & $\%$ & $\mathbf{n}$ & $\%$ & \\
\hline $\mathrm{CC}$ & 18 & 81,8 & 4 & 18,2 & 0 & 0 & 0 & 0 & 0,790 \\
\hline $\mathrm{CT}$ & 31 & 81,6 & 5 & 13,2 & 1 & 2,6 & 1 & 2,6 & \\
\hline TT & 10 & 83,4 & 1 & 8,3 & 1 & 8,3 & 0 & 0 & \\
\hline Total & 59 & 81,9 & 10 & 13,8 & 2 & 2,8 & 1 & 1,5 & \\
\hline
\end{tabular}

Kruskal-Wallis Test

TABLE IV

ASSOCIATION OF MDR1 C3435T WITH LEUKOCYTOPENIA GRADING POST CHEMOTHERAPY CYCLE 3

\begin{tabular}{|c|c|c|c|c|c|c|c|c|c|}
\hline \multirow[t]{3}{*}{ Polymorphism } & \multicolumn{6}{|c|}{ Post chemotherapy cycle III } & & & $\mathbf{P}$ \\
\hline & \multicolumn{2}{|c|}{ Normal } & \multicolumn{2}{|c|}{ degree I } & \multicolumn{2}{|c|}{ degree II } & \multicolumn{2}{|c|}{ Degree III } & \\
\hline & $\mathbf{n}$ & $\%$ & $\mathbf{N}$ & $\%$ & n & $\%$ & $\mathbf{n}$ & $\%$ & \\
\hline $\mathrm{CC}$ & 17 & 77,4 & 3 & 13,6 & 1 & 4,5 & 1 & 4,5 & 0,476 \\
\hline $\mathrm{CT}$ & 28 & 73,6 & 7 & 18,5 & 3 & 7,9 & 0 & 0 & \\
\hline TT & 7 & 58,3 & 5 & 41,7 & 0 & 0 & 0 & 0 & \\
\hline Total & 52 & 72,2 & 15 & 20,8 & 4 & 5,6 & 1 & 1,4 & \\
\hline
\end{tabular}

Kruskal-Wallis Test

TABLE V

TREND OF ABSOLUTE LEUKOCYTE DECLINING

\begin{tabular}{|l|c|c|c|c|c|}
\hline $\begin{array}{l}\text { Absolute } \\
\text { leukocyte } \\
\text { count }\end{array}$ & Range & Mean & Median & SD & $\mathrm{p}$ \\
\hline $\begin{array}{l}\text { Pre } \\
\text { chemotherapy } \\
\text { cycle I }\end{array}$ & $3660-13840$ & 8421,67 & 8435,00 & 2125,664 & - \\
\hline $\begin{array}{l}\text { Post } \\
\text { cemotherapy } \\
\text { cycle I }\end{array}$ & $1090-25680$ & 8160 & 7315 & 3967,495 & 0,156 \\
\hline $\begin{array}{l}\text { Post } \\
\text { chemotherapy } \\
\text { cycle II }\end{array}$ & $1058-14670$ & 6941,92 & 6460 & 2884,774 & 0,015 \\
\hline
\end{tabular}




\begin{tabular}{|l|l|l|l|l|l|}
\hline $\begin{array}{l}\text { Post } \\
\text { chemotherapy } \\
\text { cycle III }\end{array}$ & $1010-14790$ & 6322,99 & 5960 & 3417,35 & 0,037 \\
\hline
\end{tabular}

Based on table 5, we can find the trend of absolute leukocyte declining with more chemotherapy cycles.

TABLE VI

DISTRIBUTION OF ALELLE AND GENOTYPE FREQUENCY MDR1 C3435T

\begin{tabular}{|c|c|c|c|l|}
\hline Genotype & CC & CT & TT & \\
\cline { 1 - 4 } Observed & 30,55 & 52,77 & 16,66 & $\begin{array}{l}\mathrm{P}= \\
0,409 \\
4\end{array}$ \\
\cline { 1 - 4 } $\begin{array}{c}\text { Expected } \\
\text { W Freq }\end{array}$ & 32 & 48 & 18 & 4 \\
\cline { 1 - 3 } & $32,65 \%$ & $48,98 \%$ & $18,37 \%$ & \\
\cline { 1 - 3 } & & $\mathrm{C}=57,14 \%$ & $\mathrm{~T}=42,96 \%$ & \\
\hline \multicolumn{2}{|c|}{ Allele Frequencies } & & & \\
\hline
\end{tabular}

\section{IV.DISCUSSION}

The breast cancer incidence varied among 4 ethnics. Several studies had confirmed female breast cancer incidence vary considerably across racial and ethnic group. Difference between incidence rates and survival rates from different ethnic resulted from culture factor and environment such as exposure to carcinogenic agents, socioeconomic factor and genetic. Unpreventable risk factor including age when get the first menarche, age when get menopause and age when born first child. These was associated with the duration of estrogen exposure. Reproductive hormones are thought to influence breast cancer risk by increasing cell proliferation [14], [15]. Majority of patients didn't have family history of breast cancer, this finding was contradictive with studies showed that women with a family history of breast cancer are at increased risk of developing breast cancer [16]. Majority of the patients had no history of contraceptive oral. The risk of breast cancer increases with age, most breast cancer are diagnosed after age 50. The contradictive finding showed that breast cancer risk factors are multifactorial [15]. From this study, frequency of polymorphism MDR1 C3435T varied among the ethnics (Table.7)
TABLE VII

GENOTYPE FREQUENCIES OF MDR1 C3435T AMONG ETHNICS

\begin{tabular}{|l|l|l|l|l|l|}
\hline $\begin{array}{l}\text { Populatio } \\
\text { n }\end{array}$ & N & \multicolumn{3}{|c|}{ C3435T (\%) } & Reference \\
\hline & & CC & CT & TT & \\
\hline Serbia & 158 & 19 & 54 & 27 & {$[17]$} \\
\hline Germany & 461 & 21 & 50 & 29 & {$[18]$} \\
\hline Jordania & 100 & 17 & 50 & 33 & {$[19]$} \\
\hline Japan & 154 & 36 & 47 & 17 & {$[20]$} \\
\cline { 2 - 6 } & 114 & 35 & 53 & 12 & {$[21]$} \\
\hline \multirow{2}{*}{ Chinese } & 200 & 30 & 53 & 17 & {$[22]$} \\
\cline { 2 - 6 } & 98 & 24 & 44 & 32 & {$[23]$} \\
\hline Malays & 99 & 25 & 46 & 28 & {$[23]$} \\
\hline Indians & 93 & 18 & 39 & 43 & {$[23]$} \\
\hline Philipines & 60 & 38 & 42 & 20 & {$[24]$} \\
\hline Indonesia & 19 & - & 26 & 74 & {$[25]$} \\
\hline Indonesia & 72 & 30,6 & 52,8 & 16,7 & This study \\
\hline & & & & & \\
\hline
\end{tabular}

The frequency of wild type and variant alleles in position 3435 detected in this study did not differ significantly from those reported for Japanese and Chinese population. Different result with Indonesia population due to different ethnic and the number of subject were fewer than subject from this study.[25] This result showed that drug response differentiation based on interindividual and interethnics difference become important for certain population.

From this study, polymorphism of MDR1 C3435T had no association with leukocytopenia. This result was relevant with several studies that showed there was no association between polymorphism of MDR1 C3435T with leukocytopenia event [26]. This result was contradictive with other study in 58 cancer patient who get docetaxel monotherapy that there was an association between homozygous variant (TT) of MDR1 C3435T with grade III leukocytopenia. [27],[28] Another study showed polymorphism of MDR1 C3435T had association with grade III and IV leukocytopenia in acute lymphoblastic leukemia patients. [29]

This contradictory result may indicate that SNP of MDR1 gene should be analyzed according to complete haplotypes. Collection of several SNP that had link were known as haplotype. The most common haplotype was the polymorphism of C3435T combined with G27T and C1236T [30]. Haploptype would be considerable for differentiation of P-gp function than just one SNP. 


\section{CONCLUSION}

There was no association of MDR1 C3435T polymorphism with leukocytopenia meanwhile there was a trend of absolute leukocyte declining with more chemotherapy cycles. A study with a larger sample size must be carried out to make definite conclusions. It is hoped therefore that pharmacologic results present here will encourage investigators to analyze haplotype of MDR1.

\section{ACKNOWLEDGEMENT}

We thank Mardiah Nasution and Indra Wahyudi for helpful assistance.

\section{REFERENCES}

[1] World Cancer Research Fund International.(2015) Breast cancer statistic [Internet]. Available from: http://www.wcrf.org/int/cancerfacts-figures/data-specific-cancers/breast-cancer-statistics

[2] Sistem Informasi Rumah Sakit (2011).Prevalensi Kanker Payudara [Internet]. Available from:http://www.sirs.buk.depkes.go.id

[3] J Crawford, DC Dale, GH Lyman, CN Crawford. ChemotherapyInduced Neutropenia. Cancer. Vol 100 (2), pp 228-37.2004

[4] Y Lalami, M Paesmans, F Muanza, M Barette, B Plehiers, L Dubreucq, et al. Can we predict the duration of chemotherapy-induced leukocytopenia in febrile neutropenic patients, focusing on regimenspecific risk factors? A retrospective analysis. Ann Oncol.Vol 17, pp 507-14. Dec 20062006

[5] C Vulsteke, D Lambrechts, A Dieudonné, S Hatse, B Brouwers, T Van Brussel, et al. Genetic variability in the multidrug resistance associated protein-1 (ABCC1/MRP1)predicts hematological toxicity in breast cancer patients receiving (neo-)adjuvant chemotherapy with 5fluorouracil, epirubicin and cyclophosphamide (FEC). Ann Oncol. pp $1-13.2013$

[6] A Tazzite, Y Kassogue, B Diakité, H Jouhadi, H Dehbi, A Benider, \& $S$ Nadifi. Association between ABCB1 C3435T polymorphism and breast cancer risk: a Moroccan case-control study and meta-analysis. BMC Genetics, Vol 17,pp 126-8. 2016

[7] K Bektas, et al. Is the MDR1 C3435T polymorphis responsible for oral mucositis in children with acute lymphoblastic leukemia? Asian Pacific Journal of Cancer Prevention, Vol .13, pp 5251-5255. 2012

[8] M Taheri, F Mahjoubi, R Omranipour. Effect of MDR1 polymorphism on multidrug resistance expression in breast cancer patients. GenetMolRes. Vol 9(1), pp 34-40. 2010

[9] M Cizmarikova, M Wagnerova, L Schonova, V Habalova, A Kohut, A Linkova, et al. MDR1 (C3435T) polymorphism: relation to the risk of breast cancer and therapeutic outcome. Pharmacogenomics J. Vol 10, pp 62-9.2010

[10] Fung KL, Gottesman MM. A synonymous polymorphism in a common MDR1 (MDR1) haplotype shapes protein function. Biochim Biophys Acta.Vol 5, pp 860-71. 2009

[11] A Owen, C Goldring, P Morgan, D Chadwick, BK Park, M Pirmohamed. Relationship between the C3435T and G2677T(A) polymorphisms in the $\mathrm{ABCB} 1$ gene and $\mathrm{P}$-glycoprotein expression in human liver. Br J Clin Pharmacol. Vol 59,pp 365-70. 2005

[12] G Sauer, A Kafka, R Grundmann, et al. Basal expression of the multidrug resistance gene 1 (MDR-1) is associated with the TT genotype at the polymorphic site C3435T in mammary and ovarian carcinoma cell lines. Cancer Lett. Vol 185,pp 79-85.2002

[13] TM Sissung, K Mross, SM Steinberg, D Behringer, WD Figg, A Sparreboom, et al. Association of ABCB1 genotypes with paclitaxelmediated peripheral neuropathy and neutropenia. Eur J Cancer. Vol 42, pp.2893-6. 2006

[14] C Morris, J Epstein, K Nassere, BM Hofer. Trends in Cancer Incidence ,Mortality,Risk Factors,Health Behaviors in California. Cancer Surveillance section. 2009. p. 17-9.
[15] A Rick, B Cammie, A Burke, T Gansler, S Gapstur, M Gaudet, et al. 2014.Breast Cancer Facts \& Figures 2013-2014. Am Cancer Soc [Internet]. Available from: http://www.cancer.org/acs/groups/content/@ research/documents/docu ment/acspc-040951.pdf

[16] GA Colditz , WC Willett , DJ Hunter . Family History, Age, and Risk of Breast Cancer, Prospective Data From the Nurses' Health Study. JAMA. Vol 270(3), pp 338-343.1993

[17] Milojkovic M, Stojnev S, Jovanovic I, Ljubisavljevic S, Stefanovic V, Sunder-plassman R. Frequency of the C1236T , G2677T / A and C3435T MDR1 gene polymorphisms in the Serbian population. Pharmacol Reports. Vol 63, pp 808-14. 2011

[18] Cascorbi I. Role of pharmacogenetics of ATP-binding cassette transporters in the pharmacokinetics of drugs. Pharmacol Ther. Vol 112,pp 457-73. 2006

[19] OF Khabour, KH Alzoubi, SI Al-Azzam, NM Mhaidat. Frequency of MDR1 single nucleotide polymorphisms in a Jordanian population, including a novel variant. Genet Mol Res. Vol 12(1), pp 801-8. Jan 2013

[20] KY Urayama, JK Wiencke, PA Buffler, AP Chokkalingam, C Metayer, JL Wiemels. MDR1 Gene Variants, Indoor Insecticide Exposure, and the Risk of Childhood Acute Lymphoblastic Leukemia. Cancer Epidemiol Biomarkers Prev.Vol 16,pp 1172-7. 2007

[21] JW Sohn, SY Lee, SJ Lee, EJ Kim, SI Cha, CH Kim, et al. MDR1 Polymorphisms Predict the Response to Etoposide-Cisplatin Combination Chemotherapy in Small Cell Lung Cancer. Jpn J Clin Oncol. Vol 36(3), pp 137-41. 2006

[22] G Zhou, X Zhang.(2012)Multidrug Resistence and Breast Cancer. In: Aft R, editor. Multidrug Resistence and Breast Cancer, Targeting New Pahways and Cell Death in Breast Cancer. Shanghai: InTech;. p. 13147. Available from: www.intechopen.com

[23] C Balram, A Sharma, C Sivathasan, EJD Lee. Frequency of C3435T single nucleotide MDR1 genetic polymorphism in an Asian population : phenotypic - genotypic correlates. Br J Clin Pharmacol. Vol 56, pp 78-83.2003

[24] JH Lin, M Yamazaki. Role of P-Glycoprotein in Pharmacokinetics Clinical Implications. Clin Pharmacokinet. Vol 42(1),pp 59-98. 2003

[25] A Ashariati. Polymorphism C3435T of The MDR-1 Gene Predict Response to Preoperative Chemotherapy in Locally Advanced Breast Cancer with Her2 / neu Expression. Acta Med Indones-Indones J Inter Med. Vol 40(4),pp 187-91. 2008

[26] H Chang, SY Rha, H Jeung, C Im, JB Ahn, WS Kwon, et al. Association of the ABCB1 gene polymorphisms 2677G > T / A and $3435 \mathrm{C}>\mathrm{T}$ with clinical outcomes of paclitaxel monotherapy in metastatic breast cancer patients. Ann Oncol. Vol 2677,pp 1-6.2008

[27] A Tran, V Jullien, J Alexandre, E Rey. Pharmacogenetics And Genomics Pharmacokinetics and toxicity of docetaxel: Role of CYP3A, MDR1, and GST polymorphisms. Clin Pharmacol Ther, Vol 79(6), pp 570-81. 2006

[28] TM Sissung, K Mross, SM Steinberg, D Behringer, WD Figg, A Sparreboom, et al. Association of ABCB1 genotypes with paclitaxelmediated peripheral neuropathy and neutropenia. Eur J Cancer. Vol 42, pp 2893-6.2006

[29] DJ Erdélyi, E Kámory, A Zalka, AF Semsei, B Csókay, H Andrikovics, et al. The role of ABC-transporter gene polymorphisms in chemotherapy induced immunosuppression, a retrospective study in childhood acute lymphoblastic leukaemia. Cell Immunol. Vol 244(2), pp 121-4. 2006

[30] DL Kroetz, CP Ã, LM Hodges, CC Huang, M Kawamoto, SJ Johns, et al. Sequence diversity and haplotype structure in the human ABCB1 ( MDR1 , multidrug resistance transporter ) gene. Pharmacogenetics. 2003; 13:481-94. 